\title{
PHYSICAL, TEXTURAL AND SENSORY CHARACTERISTICS OF COLD-SPREADABLE RECOMBINED BUTTER FORTIFIED WITH CHEMICALLY INTERESTERIFIED GAMMA-LINOLENIC ACID
}

Fatouh, A. E. M.

Food Science Department, College of Agriculture, Ain Shams University, Shoubra El-Khamia, Cairo, Egypt.

\begin{abstract}
Cold-spreadable butter (CSB) was made using chemically interesterified butter oil (IEBO) with gamma-linolenic acid (GLA). Results showed that changes occurred in fatty acids (FAs) profile of butter oil (BO) by chemical interesterification were reflected on the resultant CSB characteristics. Melting enthalpy and temperature of CSB made with IEBO, were significantly lower $(P<0.05)$ than butter made using $\mathrm{BO}$ only (control). At any measured temperature; control butter displayed higher $(P<0.05)$ solid fat content (SFC) than butter made with IEBO. SFC of butter made with BO and EIBO was 45.8 and $18.2 \%$, respectively at $5{ }^{\circ} \mathrm{C}$. CSB produced using IEBO was softer $(P<0.05)$ than the control indicating an improved spreadability which was confirmed by sensory evaluation.
\end{abstract}

Keywords: Butter oil, cold-spreadable butter, chemical interesterification, gamma linolenic acid

\section{INTRODUCTION}

Milk fat possesses a unique, luxurious flavor and characteristics such as mouth feel which are highly desirable to the human palate. It is perceived by consumers as a high quality natural product, which makes high fat dairy products like cream and butter an essential ingredient in so many foods.

Normally butter is spreadable if left out of the refrigerator. The reason butter spreads so poorly when cold, compared with margarine, is its high SFC at refrigerator temperature (Hartel and Kaylegian, 2001). This lack of spreadability, combined with negative consumer health perceptions, is the main factors behind a long-term decline in butter consumption. To overcome these problems and without losing butter special eating qualities, dairy technology has focused on producing CSB.

CSB can be produced by different techniques. When using milk fat fractions, very low melting fractions (melting point $<10^{\circ} \mathrm{C}$ ) are blended with cream, then the blend is churned, or $70-80 \%$ very low melting fractions are combined with $20-30 \%$ very high melting fractions (melting point $>45{ }^{\circ} \mathrm{C}$ ) then a reconstitution process using skim milk, salt and an emulsifier is performed (Kaylegian and Lindsay, 1992; Deffense, 1993; Schaap, 1993; Arora and Rai, 1999). Feeding dairy cows protected fats, like soybean oil and flaxseed oil, results in milk fat containing high amount of unsaturated fatty aids (USFAs). Churning this milk fat produces a fairly CSB (Lin et al., 1996). In this context, there are two ways for protecting dietary lipids from rumen bihydrogenation : i) by conversion to $\mathrm{Ca}$ salt which is insoluble in the rumen (Chouinard et al., 1998), ii) encapsulating with a layer of formaldehydetreated protein like casein (Goodridge et al.,2001; Gulati et al., 2002). Protecting dietary lipids allows the lipid to bypass the rumen reactions and be 
released later in the acidic conditions of the abomasums (Kennely, 1996). The simplest way for improving butter spreadability at refrigerator temperature is blending milk fat with vegetable oils like canola oil or sunflower oil (Ahmed et al., 1979; Wilbey, 1994, Rousseau and Marangoni, 1999). However, blending milk fat with nondairy fats encounters an objection owing to the restrict legislations to the legal definition of butter (contains at least 80 $\%$ milk fat). The product in this case is called a dairy spread instead of butter (Gupta and de Man, 1985). Modifying milk fat composition through interesterification with novel polyunsaturated fatty acids like gamma-linolenic acid (Fatouh et al., 2009) and conjugated linoleic acid (Garcia et al., 2001) would produce milk fat that is suitable for producing CSB.

The objective of the present study is to fulfill the ongoing quest for producing butter with a high nutritional value and an improved spreadability

\section{MATERIALS AND METHODS}

Butter, butter milk powder, skim milk and table salt were purchased from a local grocery store.

Anhydrous butter oil (BO) was prepared by melting butter at $60{ }^{\circ} \mathrm{C}$, decanting the top oil layer, filtering the oil through glass wool, and re-filtering it under vacuum (Whatman no. 1 and $0.14 \mathrm{MPa}$ ) to obtain clear oil. The resultant BO was dried over anhydrous sodium sulfate (Amer et al., 1985).

Chemical interesterification of $\mathrm{BO}$ and GLA was performed as previously reported by Fatouh et al. (2009). IEBO obtained after $90 \mathrm{~min}$ of interesterification was chosen (Table 1).

CSB was made according to the method of Kaylegian and Lindsay (1992) as modified by Rousseau and Marangoni (1999). The overall composition of the butter included: a lipid phase $(80 \% \mathrm{w} / \mathrm{w})$ consisted of $\mathrm{BO}$ or IEBO, and an aqueous phase (20\% w/w) consisted of $18.5 \%$ skim milk, $1.2 \%$ table salt, and $0.3 \%$ butter milk powder to enhance emulsion stability.

The lipid phase was completely melted at $60{ }^{\circ} \mathrm{C}$ to destroy any crystals history. The butter milk powder and table salt were dissolved by thoroughly stirring in skim milk. Both the lipid and aqueous phases were poured into a high speed mixer and vigorously mixed for 2 min to emulsify them. The butter emulsion $\left(40^{\circ} \mathrm{C}\right)$ was then poured into an ice cream maker, which featured a double insulated bowl with a liquid refrigerant located between the walls. Churning lasted for $15 \mathrm{~min}$ with the final butter temperature of $7-8^{\circ} \mathrm{C}$. The butter was tempered at room temperature $\left(20-22{ }^{\circ} \mathrm{C}\right)$ for $4 \mathrm{~h}$ and then was worked vigorously with a hand mixer until the texture was smoothed, and any lumps were removed. The butter was then stored at $5{ }^{\circ} \mathrm{C}$ for two days prior to any experimental usage.

Thermal characteristics of CSB made with IEBO and the control butter, were performed by Differential Scanning Calorimeter (DSC) (Model 7, Perkin Elmer, Norwalk, CT, USA). The DSC was calibrated with Indium (m.p.156.60 ${ }^{\circ} \mathrm{C}, \Delta \mathrm{H}_{f} 28.45 \mathrm{~J} / \mathrm{g}$ ) and Gallium (m.p.29.78 ${ }^{\circ} \mathrm{C}, \Delta \mathrm{H}_{f} 80.09 \mathrm{~J} / \mathrm{g}$ ). The system was purged with $\mathrm{N}_{2}$ at $20 \mathrm{~mL} / \mathrm{min}$ during the analysis, and liquid nitrogen was used as a refrigerant to cool the system. AOCS method Cj-94 (AOCS, 1998) was followed. A sample of $9-10 \mathrm{mg}$ was hermetically sealed in 
a $30 \mu \mathrm{L}$ capacity aluminum pan (Perkin Elmer, Norwalk, CT, USA), with an empty sealed pan used as a reference. The sample was rapidly heated $\left(100^{\circ} \mathrm{C} / \mathrm{min}\right)$ from room temperature to $80^{\circ} \mathrm{C}$ and held at this temperature for $5 \mathrm{~min}$ before being cooled to $-50^{\circ} \mathrm{C}$ at a rate of $10^{\circ} \mathrm{C} / \mathrm{min}$. After $15 \mathrm{~min}$ holding at $-50^{\circ} \mathrm{C}$, the sample was heated to $70^{\circ} \mathrm{C}$ at a rate of $10^{\circ} \mathrm{C} / \mathrm{min}$. Thermograms were analyzed for peak melting temperature $\left(T_{p}\right)$ and melting enthalpy $\left(E_{p}\right)$.

SFC was measured with a pulsed nuclear magnetic resonance spectrometer (Maran, Resonance Instruments, Whitney, UK) operating at $20 \mathrm{MHz}$. SFC was determined according to the AOCS method Cd 1681(AOCS, 1998).

Hardness was measured at $5{ }^{\circ} \mathrm{C}$ using a TA-XT2 texture analyzer (Stable micro systems Ltd., London, UK) following the procedure of Kim and Akoh (2005). A $45^{\circ}$ conical probe penetrated into the sample at $1 \mathrm{~mm} / \mathrm{s}$ to a depth of $5 \mathrm{~mm}$ from the sample surface, and was withdrawn at the same speed. During penetration, the force increased up until the point of maximum penetration depth. Hardness was reported as the penetration force $\left(\mathrm{g} / \mathrm{cm}^{2}\right)$. CSB produced by IEBO as well the control butter was evaluated for its sensory properties. A score card suggested by Bodyfelt et al. (1988) was used and 10 panelists have carried out the test. Items of the score card included: Flavor (10 points), body and texture (10 points), and color and appearance (5 points).

Experiments were triplicated, and triplicate analyses were performed on each replicate. Statistical analysis was performed by the SAS General Linear Method procedure (SAS, 1994). Differences were considered significant at $P<0.05$.

\section{RESULTS AND DISCUSSION}

DSC thermal properties including peak melting temperature $\left(T_{p}\right)$ and melting enthalpy $\left(E_{p}\right)$ are presented in Table 2. As expected, both parameters were significantly higher $(P<0.05)$ in the control butter made by BO. CSB made with IEBO revealed a reduction by $37.4 \%$ and $17.6{ }^{\circ} \mathrm{C}$ in $E_{p}$ and $T_{p}$, respectively, as compared to the control. This shift in $E_{p}$ and $T_{p}$ values can be ascribed to the effect of chemical interesterification on the FAs composition (Table 1). Unlike BO, where saturated fatty acids (SFAs) dominated the fatty acids profile $(65.8 \%)$, USFAs of EIBO were the major component $(59.8 \%)$. The impact of USFAs on the reduction of the thermal properties is relevant to the dilution effect caused by incorporating GLA which has a very low melting point of $(-12)-(-14){ }^{\circ} \mathrm{C}$ as well as $E_{p}$ of $1.22 \mathrm{~J} / \mathrm{g}$ (Clough, 2001). This result matches well with the spreadability desired in CSB , that is stored and served on refrigerator temperature.

Rousseau and Marangoni (1999) reported a $T_{p}$ of $33.4^{\circ} \mathrm{C}$ and $30.9^{\circ} \mathrm{C}$ for CSB prepared using butter fat only and that prepared using chemically interesterified butter fat-canola oil blend, respectively. Similar observations were reported by Kim and Akoh (2005).

Poor spreadability of butter relates to the effect of temperature on solid fat content (SFC). At lower temperatures, high melting triacylglycerols 
Fatouh, A. E. M.

crystallize into the fat network making it firmer (Shukla and Rizvi, 1995). SFCtemperature profiles of the control butter and CSB made using IEBO are shown in Fig 1. At any measured temperature in a temperature range of 0-50 ${ }^{\circ} \mathrm{C}$, control butter displayed higher $(P<0.05)$ SFC than butter made with IEBO. At $5{ }^{\circ} \mathrm{C}, \mathrm{SFC}$ of the control was higher than IEBO butter by $27.6 \%$. As the temperature increased, SFC of the control and CSB made with IEBO gradually decreased until complete melting at 45 and $25^{\circ} \mathrm{C}$, respectively. For good spreadability at refrigerator temperature, SFC of butter should be less than $30 \%$ (Wright et al., 2001). Evidently, alteration of SFC profile resulted from changes took place in FAs composition of $\mathrm{BO}$ through chemical interesterification with GLA (Table 1). SFAs content of BO was reduced by 25 $\%$ with a corresponding increase in USFAs by the same value, and that replacement was GLA. GLA as a poly-unsaturated fatty acid has a very low melting point of $(-12)-(-14)^{\circ} \mathrm{C}$ as compared to SFAs being existed in BO like myristic $\left(54.4^{\circ} \mathrm{C}\right)$, palmitic $\left(62.9^{\circ} \mathrm{C}\right)$ and stearic $\left(69.6^{\circ} \mathrm{C}\right)($ Formo, 1979).

SFC results are in agreement with Rousseau and Marangoni (1999), who found a pronounced decrease in SFC of CSB prepared using chemically interesterified butter fat-canola oil blend. Kim and Akoh (2005) prepared CSB by blending butter fat with i) canola oil and ii) synthesized structured lipid made from canola oil and caprylic acid. At $5{ }^{\circ} \mathrm{C}$, SFC was 28.5 and $28.9 \%$ for the former and the later respectively, while SFC of the control butter was 39.2 $\%$.

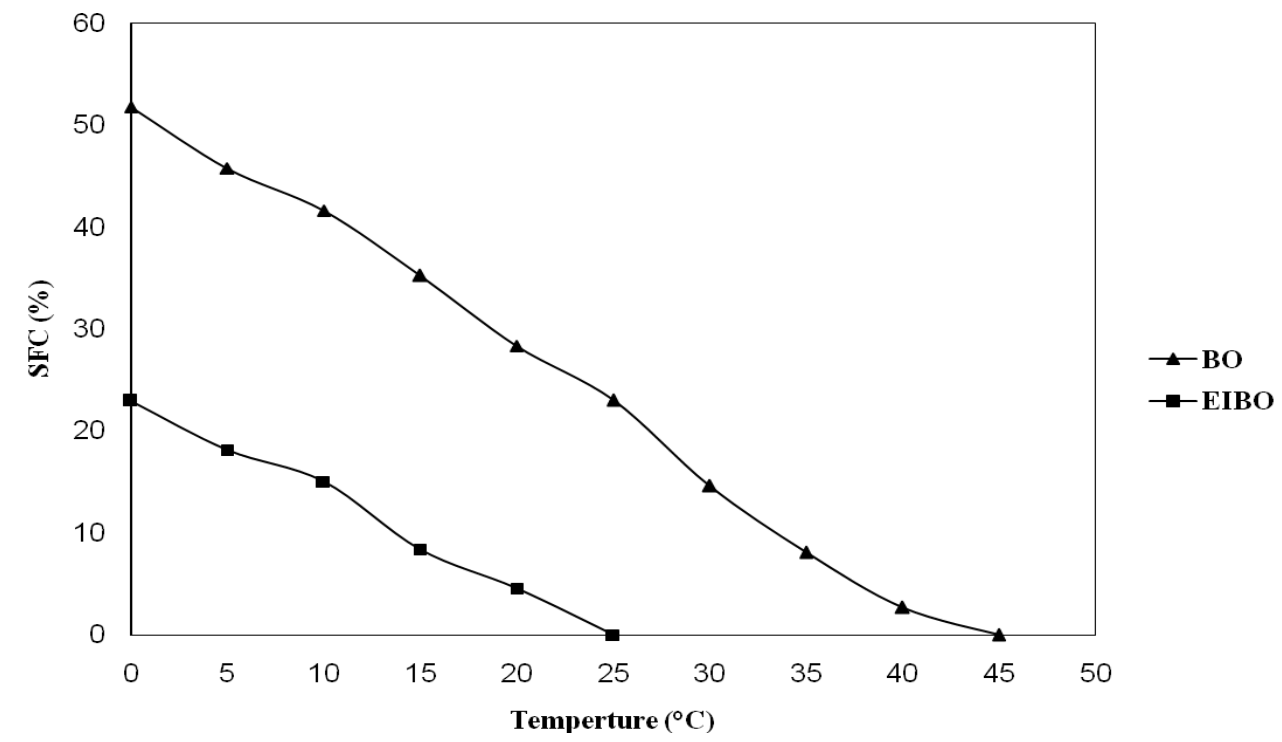

Fig. 1: Solid fat content (\% SFC) of cold-spreadable recombined butter fortified with chemically interesterified gamma-linolenic acid as a function of temperature 
Table 1: Fatty acids profile of butter oil and chemically interesterified butter oil with gamma-linolenic acid.

\begin{tabular}{lcc}
\hline FA & BO & IEBO \\
\hline $\mathbf{C}_{6: 0}$ & $1.30 \pm 0.09 \mathrm{a}$ & $0.18 \pm 0.02 \mathrm{~b}$ \\
$\mathbf{C}_{8: 0}$ & $1.17 \pm 0.12 \mathrm{a}$ & $0.13 \pm 0.01 \mathrm{~b}$ \\
$\mathbf{C}_{10: 0}$ & $2.68 \pm 0.02 \mathrm{a}$ & $0.59 \pm 0.07 \mathrm{~b}$ \\
$\mathbf{C}_{12: 0}$ & $3.41 \pm 0.02 \mathrm{a}$ & $1.04 \pm 0.01 \mathrm{~b}$ \\
$\mathbf{C}_{14: 0}$ & $11.62 \pm 0.04 \mathrm{a}$ & $6.61 \pm 0.13 \mathrm{~b}$ \\
$\mathbf{C}_{14: 1}$ & $0.97 \pm 0.01 \mathrm{a}$ & $0.40 \pm 0.01 \mathrm{~b}$ \\
$\mathbf{C}_{15: 0}$ & $1.16 \pm 0.02 \mathrm{a}$ & $0.46 \pm 0.04 \mathrm{~b}$ \\
$\mathbf{C}_{16: 0}$ & $31.82 \pm 0.06 \mathrm{a}$ & $24.16 \pm 0.30 \mathrm{~b}$ \\
$\mathbf{C}_{16: 1}$ & $1.63 \pm 0.01 \mathrm{a}$ & $1.00 \pm 0.03 \mathrm{~b}$ \\
$\mathbf{C}_{18: 0}$ & $12.66 \pm 0.04 \mathrm{a}$ & $7.05 \pm 0.12 \mathrm{~b}$ \\
$\mathbf{C}_{18: 1}$ & $27.40 \pm 0.06 \mathrm{a}$ & $20.82 \pm 0.18 \mathrm{~b}$ \\
$\mathbf{C}_{18: 2}(\mathrm{G})$ & $9.35 \pm 0.6 \mathrm{a}$ \\
$\mathbf{C}_{18: 3}$ (G6) & $3.65 \pm 0.01$ & $27.81 \pm 0.47$ \\
$\mathbf{C}_{18: 3}$ (G3 & ND & $0.40 \pm 0.04 \mathrm{~b}$ \\
& $0.54 \pm 0.02 \mathrm{a}$ & \\
SFA & & $40.22 \pm 1.00 \mathrm{~b}$ \\
USFA & $65.82 \pm 0.11 \mathrm{a}$ & $59.78 \pm 0.95 \mathrm{a}$ \\
\hline
\end{tabular}

Mean \pm S.D, $n=3$.

Different letters within the same row are significantly different $(P<0.05)$.

BO, butter oil; IEBO, interesterified butter oil; GLA, gamma-linolenic acid; ND, not detected.; SFA, saturated fatty acids; USFA, unsaturated fatty acids

Table 2: Melting temperature and enthalpy of cold-spreadable recombined butter fortified with chemically interesterified gamma-linolenic acid.

\begin{tabular}{lcccc}
\hline & \multicolumn{2}{c}{ Melting temperature $\left({ }^{\circ} \mathbf{C}\right)$} & \multicolumn{2}{c}{ Melting enthalpy $(\mathbf{J} / \mathbf{g})$} \\
\hline & BO & IEBO & BO & IEBO \\
\hline $\mathbf{R}_{\mathbf{1}}$ & 31.16 & 14.73 & 90.89 & 55.70 \\
$\mathbf{R}_{\mathbf{2}}$ & 31.80 & 14.46 & 91.45 & 54.95 \\
$\mathbf{R}_{\mathbf{3}}$ & 31.57 & 14.25 & 91.12 & 54.18 \\
Mean \pm S.D & $31.51 \pm 0.32 \mathrm{a}$ & $14.48 \pm 0.24 \mathrm{~b}$ & $91.15 \pm 0.28 \mathrm{a}$ & $54.94 \pm 0.76 \mathrm{~b}$ \\
\hline $\mathbf{n = 3 .}$
\end{tabular}

$n=3$.

Different letters within the same row are significantly different $(P<0.05)$.

BO, butter oil; IEBO, interesterified butter oil; $R$, replicate.

Regarding the textural properties of butter, hardness and spreadability are inversely related parameters. They have been the most commonly measured characteristics as they greatly influence consumer acceptability (Wright et al., 2001). Butter hardness was measured by texture profile analysis (Table 3). CSB produced by using IEBO was softer $(P<0.05)$ than the control. Using IEBO has reduced the force required for penetration by $38.4 \%$ indicating that butter spreadability has improved. This result is readily explained based on FAs composition of both $\mathrm{BO}$ and IEBO. BO contains $65.8 \%$ and $34.2 \%$ of SFAs and USFAs respectively, while IEBO 
contains $40.2 \%$ and $59.8 \%$ following the same order (Table 1). A great portion $(46.5 \%)$ of IEBO USFAs content is GLA, which means lower SFC at refrigerator temperature, hence much better spreadability.

In accordance with the obtained results, Rousseau and Marangoni (1999), who reported an increase by more than $50 \%$ in penetration depth when using cone penetromatry for CSB prepared using chemically interesterified butter fat-canola oil blend. Kim and Akoh (2005) confirmed the same trend when found that CSB prepared with butterfat-canola oil blend and butterfat- structured lipid (made from canola oil and caprylic acid) blend was significantly $(P<0.05)$ softer as compared to the control made by butter fat only.

Table 3: Hardness (at $5{ }^{\circ} \mathrm{C}$ ) of cold-spreadable recombined butter fortified with chemically interesterified gamma-linolenic acid.

\begin{tabular}{lcc}
\hline & \multicolumn{2}{c}{ Hardness $\mathbf{( \mathbf { g } / \mathbf { c m } ^ { 2 } )}$} \\
\hline $\mathbf{R}_{\mathbf{1}}$ & $\mathbf{B O}$ & IEBO \\
$\mathbf{R}_{\mathbf{2}}$ & 1572.13 & 1012.75 \\
$\mathbf{R}_{\mathbf{3}}$ & 1649.05 & 985.73 \\
Mean士S.D. & 1618.67 & 978.51 \\
\hline $\boldsymbol{n}=\mathbf{3}$ & $1613.28 \pm 38.74 \mathrm{a}$ & $992.33 \pm 17.86 \mathrm{~b}$ \\
\hline
\end{tabular}

Different letters within the same row are significantly different $(P<0.05)$.

BO, butter oil; IEBO, interesterified butter oil; R, replicate.

Results of sensory assessment of the control butter and butter made using IEBO are shown in Table 4. Panelists were asked to judge flavor, body and texture (mainly spreadabilty) and appearance. As expected for spreadability, CSB made using IEBO scored higher $(P<0.05)$ than the control which was harder at refrigerator temperature. Both butters did not show significant differences $(P<0.05)$ in the appearance. For the flavor, also both butters did not show significant differences $(P<0.05)$; however, the panelist pointed out that CSB made with IEBO somewhat lacks the typical buttery flavor. This altered flavor might be due to the used catalyst during chemical interesterification of milk fat and GLA (Mickle et al., 1961; Rousseau and Marangoni, 1999). More research has to be forward for improving the flavor of CSB prepared by IEBO. 
Table 4: Sensory evaluation of cold-spreadable recombined butter fortified with chemically interesterified gamma-linolenic acid.

\begin{tabular}{lcccccc}
\hline & \multicolumn{2}{c}{ Flavor (10) } & \multicolumn{2}{c}{ Body and texture (10) } & \multicolumn{2}{c}{ Appearance (5) } \\
\hline & BO & IEBO & BO & IEBO & BO & IEBO \\
\hline $\mathbf{R}_{\mathbf{1}}$ & 9.38 & 8.72 & 5.52 & 8.71 & 5.13 & 4.37 \\
$\mathbf{R}_{\mathbf{2}}$ & 8.76 & 8.41 & 4.01 & 9.35 & 4.40 & 4.45 \\
$\mathbf{R}_{\mathbf{3}}$ & 9.04 & 8.03 & 4.37 & 9.73 & 4.71 & 4.70
\end{tabular}

Mean \pm S.D. $9.07 \pm 0.31$ a $8.39 \pm 0.35 a$ 4.63 \pm 0.79 b $9.26 \pm 0.52$ a $4.75 \pm 0.37$ a $4.51 \pm 0.17 \mathrm{a}$ $n=3$.

Different letters within the same row are significantly different $(P<0.05)$.

BO, butter oil; IEBO, interesterified butter oil; $R$, replicate.

\section{Abbreviations used}

BO, butter oil; CSB, cold-spreadable butter; DSC, differential scanning calorimeter; IEBO, interesterified butter oil; $E_{p}$, melting enthalpy; FAs, fatty acids; GLA, gamma-linolenic acid; SFAs, saturated fatty acids; SFC, solid fat content; $T_{p}$, melting temperature; USFAs, unsaturated fatty acids.

\section{Acknowledgment}

This study was supported by a grant from US-Egypt junior scientists exchange visiting program between Scientific Research Academy, Ministry of Scientific Research, Cairo, Egypt and USAID program, USA. The author would like to express his gratitude to the staff members of the Food Science Department of the University of Georgia, Athens, USA for providing me the required facilities to execute this research .

\section{REFERENCES}

Ahmed, N.S.; Helal, F.R. and EL-Nimr, A.A. (1979). Modified butter containing vegetable oils. Milchwissenschaft, $34: 218-219$

Amer, M. A., Kupranycz, D. B. and Baker, B. E. (1985). Physical and chemical characteristics of butterfat fractions obtained by crystallization from molten fat. J.Am. Oil Chem.Soc., 62: 1551-1557.

AOCS (1998). Official Methods and Recommended Practices of the American Oil Chemists' Society, $5^{\text {th }}$ ed. Firestone, D. (Ed.), American Oil Chemists' Society, Champaign, IL, USA.

Arora, S. and Rai, T. (1999). Effect of incorporation of low melting fat fractions from goat milk on the physical properties and sensory scores of butter. J. Dairying, Food \& Home Sci., 18:.32-36.

Bodyfelt, F.W.; Tobias, J and Trout, G.M. (Eds.) (1988). Sensory evaluation of butter. In. The Sensory Evaluation of Dairy Products, Van Nostrand Reinhold, NY, USA.

Clough P. M. (2001), Speciality vegetable oils containing ã-Linolenic acid and stearidonic, In: Structured lipids, Gunstone, F.D. (Ed.), Marcel Dekker Inc., NY, USA. 
Chouinard, P. Y.; Girard, V. and Brisson, G. J. (1998). Fatty acid profile and physical properties of milk fat from cows fed calcium salts of fatty acids with varying unsaturation. J.Dairy Sci., 81: 471-481.

Deffense, E. (1993). Milk fat fractionation today: A review. J.Am. Oil Chem. Soc., 70: 1193-1201.

Fatouh, A.E.; Singh, R.K. and Pegg, R. B. (2009). Chemical interesterification of milk fat and gamma-linolenic acid derived from Borage oil (Borago officinalis L) J. Bio. Chem. Environ. Sci., 4:39-44

Formo, M.W. (1979). Physical properties of fats and fatty acids. In: Bailey`s Industrial Oil and Fat Products, Swern, D. (Ed.), John Willey \& Sons, NY, USA.

Garcia,H.S.; Arcos, J.A.; Keough, K.J. and Hil Jr., C.G. (2001). Immobilized lipase- mediated acidolysis of butteroil with conjugated linoleic acid: batch reactor and packed bed reactoe studies. J. Molecular Catalysis B: Enzy., 11:623-632.

Goodridge, J.; Ingalls, J. R. and Crow, G. H. (2001). Transfer of omega-3 linolenic acid and linoleic acid to milk fat from flaxseed or linola protected with formaldehyde. Canad. J. Animal Sci., 81:525-532.

Gulati, S. K.; May, C.; Wynn, P. C. and Scott, T. W. (2002). Milk fat enriched in $n-3$ fatty acids. Animal Feed Sci. Technol., 98: 143-152.

Gupta, S. and de Man, J.M. (1985). Modification of rheological properties of butter. Milchwissenschaft, 40: 321-325.

Hartel, R. W. and Kaylegian, K. E. (2001). Advances in milk fat fractionation: Technology and applications. In Crystallization processes in fats and lipid systems. Garti, N. and Sato, K. (Eds.). Marcel Dekker, Inc., NY, USA, pp. 381-427.

Kaylegian, K. E. and Lindsay, R. C. (1992). Performance of selected milk fat fractions in cold-spreadable butter. J.Dairy Sci., 75: 3307-3317.

Kennelly, J. J. (1996). The fatty acid composition of milk fat as influenced by feeding oilseeds. Animal Feed Sci. Technol., 60: 137-152.

Kim, B.H. and Akoh, C.C. (2005). Chemical and physical properties of butterfat-vegetable oil blend spread prepared with enzymatically transesterified canola oil and caprylic acid. J. Agric. Food Chem, 53: 4954-4961.

Lin, M.P.; Sims,C.A.; Staples, C.R. and O'Keefe, S.F. (1996). Flavor quality and texture of modified fatty acid high-monoene, low saturate butter. Food Res. Int., 29: 367-371.

Mickle, J.B.; von Gunten, R.L. and Morrison, R.D. (1963). Rearrangment of milk fat as a means of adjusting hardness of butterlike products. J. Dairy Sci., 46:1357-1360.

Rousseau, D. and Marangoni, A.G. (1996). The effect of interesterification on physical and sensory attributes of butterfat and butterfat-canola oil spreads. Food Res. Int., 31: 381-388.

SAS User's Guide Statistics (1994). SAS Institute Inc., Cary, NC, USA.

Schaap, J. E. (1993). The influence of the crystal mass in the fat on the spreadability of butter. IDF special issue; no. 9303, pp. 408-412. 
Wilbey, R.A. (1994). Production of butter and dairy based spreads. In: Modern Dairy Technology, vol.1, Advances in Milk Processing, Robinson, R.K. (Ed.). Chapman and Hall, NY, USA.

Wright, A.J.; Scanlon, M.G.; Hartel, R.W. and Marangoni, A.G. (2001). Rheological properties of milk aft and butter. J. Food Sci., 66: 10561071.

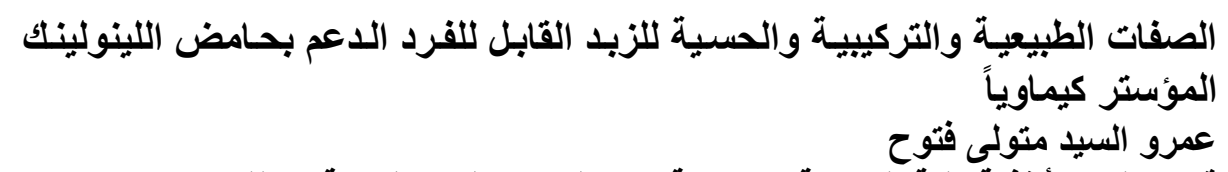
قسم علوم الأغذية كلية الزراعة فئول ـ جامعة عين شمس- شبرا الخيمة ــ القاهرة ـ مصر

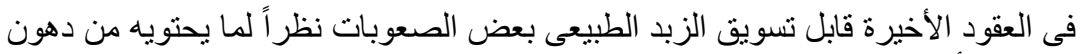

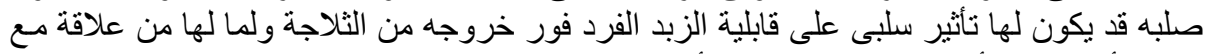

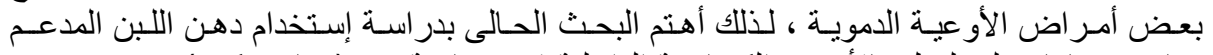

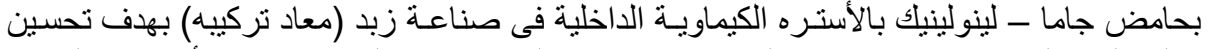

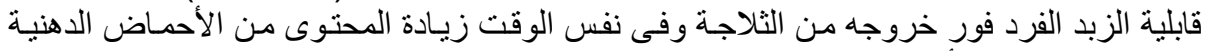

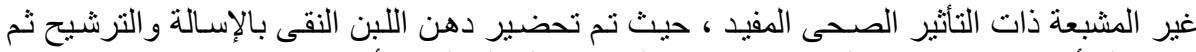

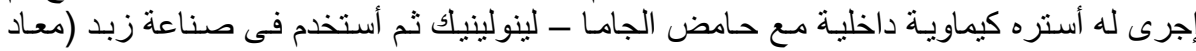

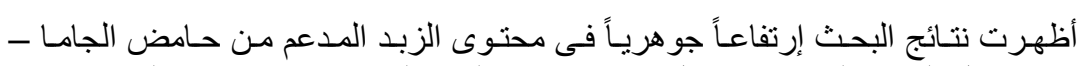
نركيبه)

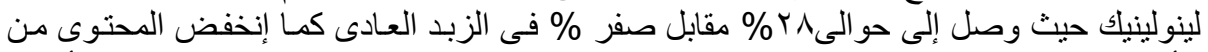

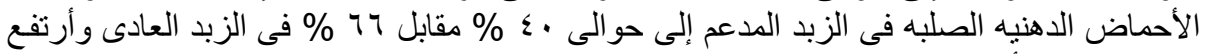

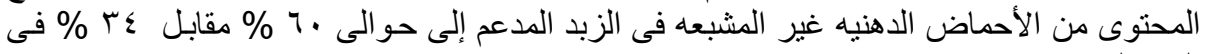

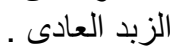

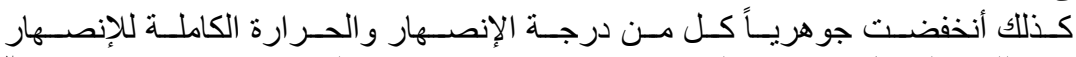

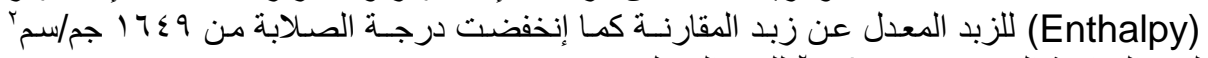

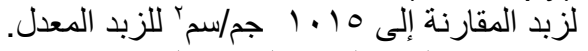

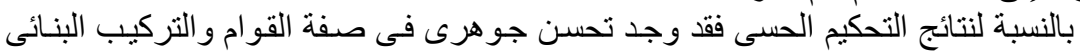

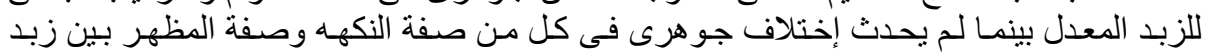

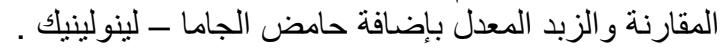

